Relations industrielles

Industrial Relations

\title{
Denis Boucher et Christian Doyon, La sélection du personnel: pour trouver l'excellence
}

\section{Denis Morin}

Volume 47, numéro 2, 1992

URI : https://id.erudit.org/iderudit/050784ar

DOI : https://doi.org/10.7202/050784ar

Aller au sommaire du numéro

Éditeur(s)

Département des relations industrielles de l'Université Laval

ISSN

0034-379X (imprimé)

1703-8138 (numérique)

Découvrir la revue

Citer ce compte rendu

Morin, D. (1992). Compte rendu de [Denis Boucher et Christian Doyon, $\mathrm{La}$ sélection du personnel: pour trouver l'excellence]. Relations industrielles / Industrial Relations, 47(2), 391-393. https://doi.org/10.7202/050784ar

Tous droits réservés (C Département des relations industrielles de l'Université Laval, 1992
Ce document est protégé par la loi sur le droit d'auteur. L'utilisation des services d'Érudit (y compris la reproduction) est assujettie à sa politique d'utilisation que vous pouvez consulter en ligne.

https://apropos.erudit.org/fr/usagers/politique-dutilisation/ 
La sélection du personnel: pour trouver l'excellence, par Denis Boucher et Christian Doyon, Montréal, Éditions Agence d'Arc, 1991, 144 p., ISBN 2-89022-265-9

La prédiction de la performance des candidats dans le cadre d'un emploi et la sélection d'un candidat dont la performance sera la plus élevée constituent les principales raisons qui justifient le développement des procédures de sélection. Plus particulièrement, les diverses procédures de sélection tentent d'optimiser l'appariement de l'individu à l'emploi dans l'espoir d'intensifier la réalisation des objectifs de productivité. Des procédures de sélection valides peuvent donc accroître substantiellement l'efficacité organisationnelle.

L'ouvrage de vulgarisation de Boucher et Doyon décrit la démarche de sélection et fournit un ensemble de recommandations destinées principalement aux praticiens. Les auteurs proposent une vision systémique de la sélection du personnel qui intègre des notions dans les secteurs de la planification des ressources humaines, du recrutement, de l'entrevue de sélection, de la rémunération, de la qualité de la supervision, de la motivation et de la formation. Les concepts véhiculés tout au long de l'ouvrage s'appuient largement sur ceux que l'on retrouve dans des manuels de base en gestion des ressources humaines. Les auteurs n'apportent rien de nouveau sur le plan des connaissances dans le domaine de la sélection. Le plan de travail se résume essentiellement à présenter les étapes successives d'une démarche de sélection. A chaque étape du processus de sélection correspond un chapitre. Les chapitres se répartissent selon l'ordre suivant: la planification des ressources humaines et le recrutement, la préparation et la conduite de l'entrevue de sélection, les tests psychologiques et, enfin, l'analyse et la décision d'embauche.

Le contenu du volume est très déficient. Le traitement des activités de sélection est élémentaire. Les auteurs ne mettent pas en évidence la contribution des travaux théoriques et empiriques les plus saillants ainsi que les données de recherche les plus récentes sur le processus de sélection.

La discussion se concentre exclusivement sur les méthodes (i.e., entrevue de sélection, tests, centre d'évaluation) de sélection des candidats. Ces méthodes, que nous définissons comme étant des prédicteurs, ont pour objectif de prédire le succès à l'emploi. La notion de critère est plus importante que le concept de prédicteur lorsque nous établissons la relation entre ces deux entités. Les auteurs ont négligé de décrire ce lien. D'une façon générale, ce que l'on tente de prédire (i.e., le critère) s'avère une mesure de la contribution de l'employé à l'organisation et celle-ci s'apparente à une mesure de la performance ou du succès au travail. L'évaluation subjective du rendement constitue le critère de succès à l'emploi le plus couramment utilisé en sélection du personnel. Nous pouvons également retracer plusieurs critères plus objectifs de la performance: l'absentéisme, le taux de roulement, les accidents, les unités de production, le volume des ventes et le nombre de promotion. Ces critères du succès à l'emploi ne sont pas équivalents sur le plan psychométrique. Ainsi, lorsque nous effectuons un examen des méthodes de sélection en vue de prédire le succès à l'emploi, il est nécessaire de spécifier le critère utilisé. Boucher et Doyon ne traitent pas des multiples modèles de validation en 
sélection du personnel. Dans la même veine, les acteurs n'ont pas clarifié le rôle de l'analyse de poste dans la prédiction du succès à l'emploi.

Les auteurs n'ont pas fait appel aux divers travaux de Wanous sur l'intégration dans l'organisation (organizational entry). Nous pouvons identifier quatre thèmes de recherche qui relèvent du processus d'intégration des nouveaux venus dans l'organisation: (1) l'entrevue d'embauche réaliste; (2) l'efficacité des différentes sources de recrutement; (3) le processus par lequel les candidats choisissent les emplois et (4) la socialisation organisationnelle des nouveaux venus. Tous ces champs de recherche se concentrent sur les attitudes et les comportements des candidats lors du processus de sélection. Par ailleurs, il n'y a pas de discussion sur l'influence des comportements de l'interviewer sur le processus associé au choix de l'emploi par le candidat.

Les auteurs ne présentent aucun modèle sur le processus d'entrevue de sélection, alors qu'il en existe plusieurs (Webster, Schmitt, Arvey, Campion, Dipboye). Ces modèles permettent à la fois d'élucider les processus psychologiques de l'interviewer et d'offrir des avenues de recherche variées. Le postulat implicite qui sous tend une partie importante des modèles et des recherches est que la faible validité de l'entrevue de sélection est attribuable aux erreurs commises par les interviewers lors du traitement de l'information. Par conséquent, la majorité des travaux ont été consacrés à l'étude des caractéristiques cognitives de l'interviewer et des caractéristiques contextuelles de l'entrevue de sélection. Ces modèles ont également examiné l'influence du contexte de l'entrevue de sélection sur le processus de décision du candidat et de l'interviewer.

La distinction entre les différents types d'entrevue a été établie: l'entrevue libre, l'entrevue semi-structurée et l'entrevue structurée. Un examen comparatif de la validité, de la fidélité et de l'utilité de ces entrevues aurait été souhaitable. Les travaux de Latham, Janz et Cronshaw sont pertinents à cet égard. Les auteurs n'offrent aucune démarche rigoureuse sur l'interprétation et l'évaluation de l'information sur les candidats en vue de prendre une décision d'embauche. La discussion sur l'effet des exigences légales sur le développement des systèmes de sélection n'est pas suffisamment approfondie. Le chapitre sur les tests psychologiques présente une analyse comparative des principaux tests utilisés dans les entreprises. Les tests de connaissances, d'aptitudes, d'habiletés ainsi que d'intérêts sont évalués en fonction des critères suivants: validité, utilisation et application. Les auteurs n'ont cependant pas discuté des coûts reliés à l'utilisation de ces tests.

En conclusion, ce livre n'est définitivement pas approprié pour le milieu universitaire ni pour les praticiens. Nous pouvons douter de la qualité de nombreux propos en citant par exemple le passage suivant: "Par des observations répétées, les psychologues sont capables d'analyser certaines anomalies du corps... Prenons simplement les rides du visage. Celles-ci sont souvent, à notre insu, les marques d'un travail acharné" ( $p, 64)$. Nous espérons 
qu'un volume rigoureux et sérieux sur la sélection puisse voir le jour dans un avenir rapproché.

Denis Morin

Université Laval

Managing to Discriminate, by David L. Collinson, David Knights and Margaret Collinson, Routledge, London, 1990, 261 p., ISBN 0-415-01816-1 et ISBN 0-415-01817-X (pbk)

This book is based on a research project sponsored by the Equal Opportunities Commission in the mid 1980s. The project was designed to examine gender discrimination in recruitment. The authors have attempted to provide a theoretically informed examination of the empirical data using the case study evidence drawn from 45 private sector organizations in the banking, insurance, computer, mail order, food and manufacturing industries in England. The primary objective of the book is to explore the asymmetrical power relations of the labour market and recruitment process by focusing on the forms of control and resistance which characterise the gender discrimination in selection and promotion. Chapters 1 to 4 are devoted to a discussion and review of the theoretical studies on sex discrimination in the recruitment process. Chapters 1 and 2 present Marxist and feminist approaches to subordination of women in the labour market. These chapters contain an interesting and succinct summary of the theories which reveal the importance of power relations in the labour market. The third chapter reviews the literature in Industrial Sociology to analyze the channels, criteria and procedures of recruitment and the job segregation based on gender. Chapter four looks at the recruitment process from the management's point of view. Unfortunately, the discussion in chapter four is not comprehensive enough to uncover various legal, economic and other factors which influence managerial decision-making in relation to the recruitment process.

The rest of the book is devoted to the analysis of the case studies involving the forty-five organizations in various sectors of the economy in the U.K. The case studies reveal that despite the anti-discrimination legislation which has been in effect since mid 1970s, employers are still "managing to discriminate" on the grounds of gender through a variety of recruitment practices. The authors observe that the conventional divisions of labour at home and in employment are found to be both a routine condition and consequence of recruitment and a common means of legitimizing sex discrimination in the workplace. Their research confirmed the perpetuation of segregation both in blue collar and white collar jobs. This was characterised by a self-fulfilling vicious circle which incorporated the three key recruitment practices of "reproduction, rationalization and resistance". Informality in the channels, criteria and procedures of recruitment was a common practice in the organizations which facilitated the "reproduction" of job segregation. The personnel managers have often "rationalised" the job segregation by blaming the female applicants or employees who applied for promotion or by insisting that they were merely seeking to control production. Resistance by females was often found to be contradictory and self-defeating unless supported by the union. 